\title{
New Caledonia - a conservation imperative for an ancient land
}

\author{
R. A. Mittermeier, T. B. Werner and A. Lees
}

When Myers (1988) published his first overview of threatened hotspots for conservation of biodiversity world-wide, most of the 10 areas he selected (for example, Madagascar, the Atlantic Forest of Brazil, the eastern slope of the Andes) were already known to be critically important. However, one of his hotspots, the small island territory of New Caledonia in the South Pacific, was an unexpected inclusion in the global priority list. Although well known to botanists as a living museum of unique and ancient plants, and to marine biologists as the site of the world's second largest coastal barrier reef, New Caledonia had been largely overlooked by the international conservation community. None the less, it ranks as one of the world's most endangered biodiversity hotspots and requires an immediate and substantial commitment of conservation resources.

New Caledonia, a French Overseas Territory, lies at the southern extremity of Melanesia, some $1500 \mathrm{~km}$ east of Australia and $1700 \mathrm{~km}$ north-east of New Zealand (Figure 1). Unlike the nearby island states of Vanuatu, Solomon Islands and Fiji, which are of volcanic origin, the $16,750-\mathrm{sq}-\mathrm{km}$ main island of New Caledonia, Grand Terre, was once part of the great ancient continent of Gondwanaland, from which it became separated 65-80 million years ago (CTRDP, 1987; Salvat et al., $1953 / 1988$ ). Of more recent origin are the $1600-\mathrm{km}$-long reef that encircles Grand Terre (CTRDP, 1987) and the raised limestone Loyalty Islands to the east, which total nearly $2000 \mathrm{sq} \mathrm{km}$ in land area. The total land area of New Caledonia is thus approximately the same size as Wales, UK, or the US state of New Jersey. Despite its small size, it is biologically very diverse, with exceptional numbers of endemic taxa-much like Madagascar, another tropical island of Gondwanaland origin. The combination of high biodiversity and high threat has resulted in the identification of New Caledonia as one of the world's top ten 'threatened hotspots' (Myers, 1988, 1990), and IUCN gave New Caledonia its highest ranking for conservation importance in the entire Oceania region (IUCN, 1986).
Diversity is also a characteristic of New Caledonia's people. The population of 165,000 comprises Melanesians (45 per cent), Europeans (34 per cent), Polynesians (11 per cent) and others (10 per cent), mostly of Asian descent (Anon., 1994). The Melanesians, or indigenous Kanaks, speak 37 languages (Anon., 1989), and a large percentage of them are subsistence farmers. Although outnumbered in the territory's southern capital, Nouméa, and in Province Sud, the Kanaks comprise nearly 80 per cent of the population of Province Nord, and virtually 100 per cent of the Loyalties (Anon., 1989).

In this article we review the available information on New Caledonia's biodiversity, with particular emphasis on its remarkable floral diversity, and make specific recommendations for its conservation.

\section{Biodiversity in New Caledonia}

Over 3000 species of native plants are found in New Caledonia, 80 per cent of which occur nowhere else in the world (Schmid, 1981; Morat et al., 1984; CTRDP, 1987; Morat, 1993). Even more exceptional is the high degree of endemism at higher taxonomic levels: 14 per 


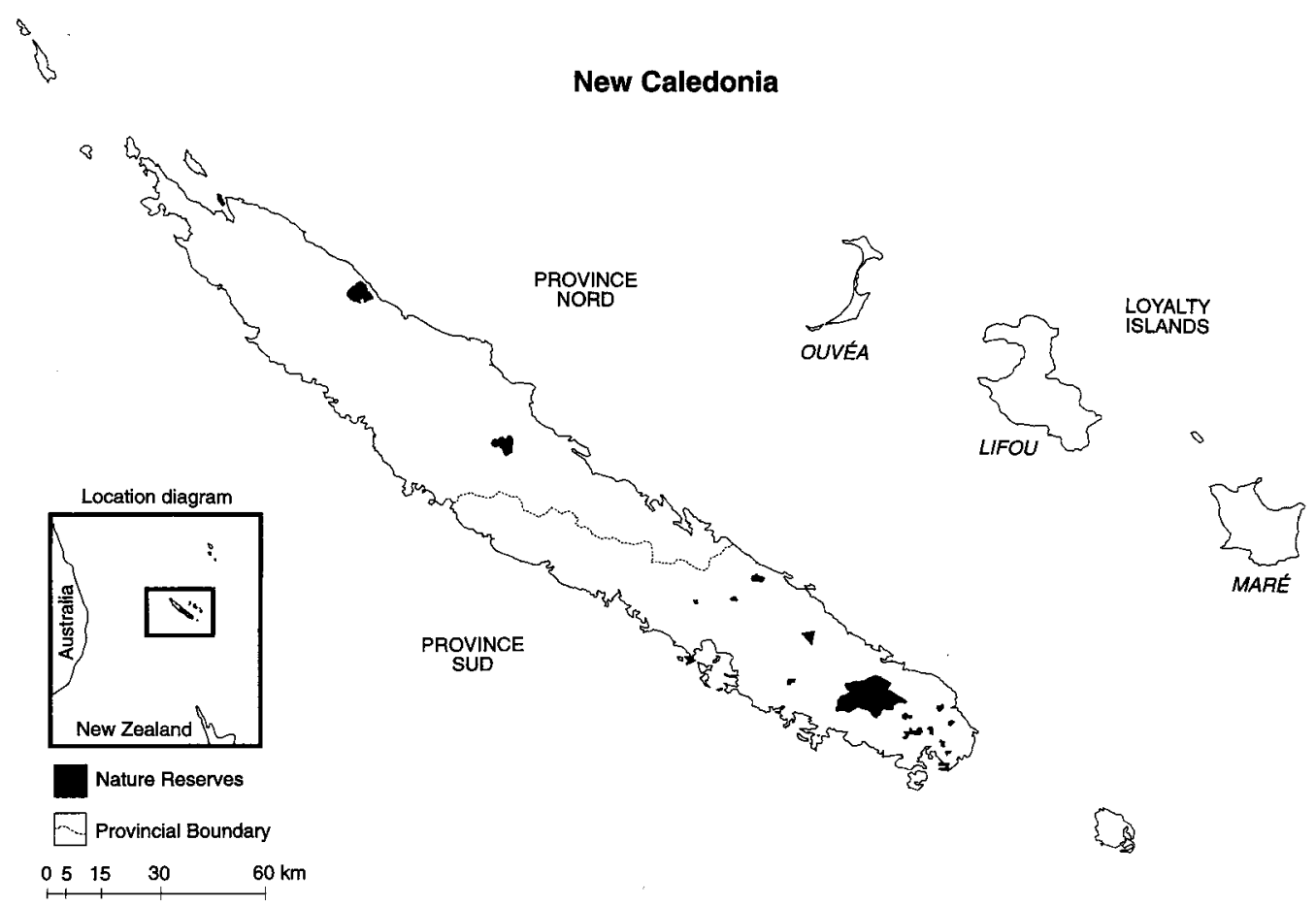

Figure 1. The French overseas territory of New Caledonia showing terrestrial nature reserves.

cent of 788 genera and five of 165 families of plants are restricted to the forests of New Caledonia (Morat et al., 1984; Morat, 1993). In the whole world, only Madagascar, Australia and Fiji share with New Caledonia the distinction of harbouring endemic families of plants (Australia with 13, Madagascar with five and Fiji with one). However, Australia is over 400 times larger and Madagascar 31 times the size of New Caledonia. The number of endemic plant taxa in New Caledonia, therefore, is truly outstanding.

Exceptional diversity and endemism also occur within certain plant groups. New Caledonia has a high number of gymnosperm species (44; Morat, 1993), all but one endemic, including the world's only parasitic conifer Parasitaxus ustus. New Caledonia harbours 19 endemic species of Araucaria, an ancient group of Gondwanaland gymnosperms, of which there are only 24 species in the world (Farjon et al., 1993). Also present are representatives of the most primitive dicotyledons, including two endemic genera of the family Winteraceae (Schmid, 1981). All 31 species of palms are endemic, representing 15 endemic genera out of a total of 16 (Jaffré and Veillon, 1988). New Caledonia's unique and ancient flora has led to its classification by many botanists as a distinct phytogeographic province (Morat et al., 1984).

For a territory the size of New Caledonia, vertebrate diversity is quite high, except for the mammals. Although its plant diversity indicates its continental origin, the mammalian fauna is characteristic of an isolated island. Only nine mammals (six endemic) are indigenous to New Caledonia and these are all bats (Flannery, 1995). Marsupials are absent from New Caledonia, not having dispersed into Australia from the Americas prior to New Caledonia's separation from Gondwanaland. However, what the territory lacks in native mammals, it makes up for in its avifauna and 
herpetofauna. Eighteen of the 116 species of birds that breed in the New Caledonia region are endemic and, of these, four represent monotypic genera (Hannecart and Letocart, 1980, 1983; Hannecart, 1988). A further 30 subspecies are found exclusively in New Caledonia.

One of the most evolutionarily interesting of New Caledonia's avifauna is the official bird of the territory, the endemic kagu Rhynocetos jubatus, the sole extant representative of the family Rhynochetidae. The kagu is found only in the remaining rain-forest habitats of New Caledonia, as is the notou Ducula goliath, the world's largest living arboreal pigeon (Hannecart, 1988).

Although no snakes or amphibians are native to the islands, there are 48 native terrestrial and 15 marine reptile species, including green, hawksbill and loggerhead sea turtles (Bauer and Sadlier, 1993; P. Pritchard, unpubl. data). This is a remarkably large herpetofauna given the small area of the territory; 40 of the native terrestrial reptiles ( 83 per cent) and nine genera - approximately half - are restricted to New Caledonia (Bauer and Sadlier, 1993). These include an ancient group of rainforest geckos, Rhacodactylus spp., which are among the world's largest geckos, and the largest of all is the New Caledonian endemic, $R$. leachianus. Although there are no major rivers in New Caledonia, over 50 species of freshwater fish are found there, including at least five introduced species (Séret, 1992).

As in most areas of the world, the invertebrate fauna contains many undescribed species. To date, 4000 insects have been described from New Caledonia, and these already demonstrate high endemism at specific and generic levels in many groups (Chazeau, 1993). The total insect fauna is projected to number 8000-20,000 species (CTRDP, 1987). Researchers have estimated New Caledonia's land snails at $200-400$ species, all restricted to the territory, representing 12 families (CTRDP, 1987). There are 64 native species of butterflies (11 endemic with two endemic genera; Holloway and Peters, 1976), and to date 194 species (in 112 genera and 33 families) of true spiders are known from New Caledonia, although this is a gross underestimate of the total fauna (Platnick, 1993). New Caledonia has the only family of spiders endemic to an island, the Bradystichidae. Brightly coloured underneath, they resemble lumps of mud when viewed from above because of the soil and other debris that adhere to the carapace (Platnik, 1993).

With its southern border just north of the Tropic of Capricorn, New Caledonia has abundant coral reefs. The ocean environment of the territory dwarfs its land mass, with a total area of $1,740,000 \mathrm{sq} \mathrm{km}$ (IUCN, 1986). A 24,000-sq-km lagoon separates Grande Terre from the barrier reef that encircles it (Salvat et al., 1953/1988), and the Loyalty Islands and other island groups of New Caledonia also have extensive reefs. The seas around New Caledonia contain over 1736 species of fish (Rivaton et al., 1989). Hard corals number approximately 108 species (UNEP/IUCN, 1988) and the marine mollusc fauna is estimated at 6500 species (Salvat et al., 1953/1988), including an estimated 100 species of Conus (CTRDP, 1987). Guile et al. (1986) recognized 240 species of echinoderms, 13 restricted to the territory's waters.

Clues to the great biological wealth of New Caledonia are revealed in its diverse ecology. A central chain of high mountains running north-west to south-east is covered by tropical rain forest. These mountains drop only a short distance to the sea on the more humid east coast; in the west they taper more gradually to dry forests, savannahs and finally to mangroves and coral reefs.

Geologically, the variety of soil substrates partly explains the unusual fauna and flora of Grande Terre. The island is unique in the extent of ultrabasic soil types that dominate about one-third of its area, primarily in the south. These soils support two habitat types: forest and maquis (scrubland). These soil types are believed to have caused plants to adapt and radiate in a way that resulted in much of the island's unique and unusual flora and its associated fauna. In fact, 72 per cent (119) of New Caledonia's plant families, 56 per cent (440) of plant genera and 58 per cent (1844) of plant species are found on these ultrabasic 
soils. Nearly 64 per cent of these species are entirely restricted to these soil types and, of these, 98 per cent are endemic to $\mathrm{New}$ Caledonia (Jaffré et al., 1987). Some animals also show this exclusive distribution with lateritic soils, including the Rhacodactylus geckos (Bauer and Vindum, 1990).

Rain forests, occupying 20 per cent of the territory, and maquis, covering 24 per cent, form the most extensive areas of native habitat types. Plant endemism in these vegetation types is high: 88 per cent for rain forest and 91 per cent for maquis (Morat, 1993). In addition, there are $200 \mathrm{sq} \mathrm{km}$ of mangroves on the west coast of Grande Terre and $100 \mathrm{sq} \mathrm{km}$ of dry or sclerophyll forest. According to Bouchet et al. (1995) New Caledonia's sclerophyll forest has been drastically reduced to just 2 per cent of its original extent and is thus highly endangered. These forests harbour many endemic species, including 59 that are found nowhere else. Unfortunately for conservation, the most extensive terrestrial habitats of New Caledonia are secondary, including herbaceous and arborescent savannahs, dominated mainly by niaoulis Melaleuca quinquenervia. The Loyalties are mostly covered by forest, although with fewer than 400 species of plants they lack the great forest diversity found on the main island (Jaffré, 1993).

\section{Threats to biodiversity}

The geological history that has resulted in such an array of organisms also created the

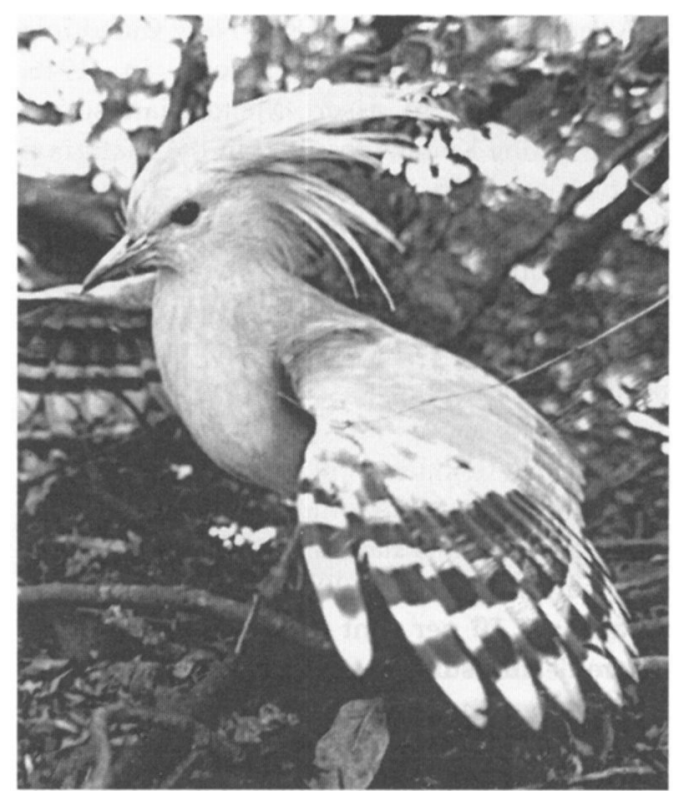

The kagu Rhynocetos jubatus, New Caledonia's endemic and national bird (R. A. Mittermeier).

world's largest known deposit of nickel. Exploitation of nickel reserves forms the foundation of New Caledonia's economy, with the first mine opening as early as 1874 . Nickel currently accounts for approximately 90 per cent of all export income, followed by tourism as the next largest contributor to foreign earnings. Only 1.6 per cent of the country's GDP comes from agriculture and fisheries, and most agriculturally productive land is used for raising livestock, primarily cattle and pigs (Anon., 1994).
A large gecko, Rhacodactylus auriculatus; the genus is endemic to New Caledonia (R. A. Mittermeier).

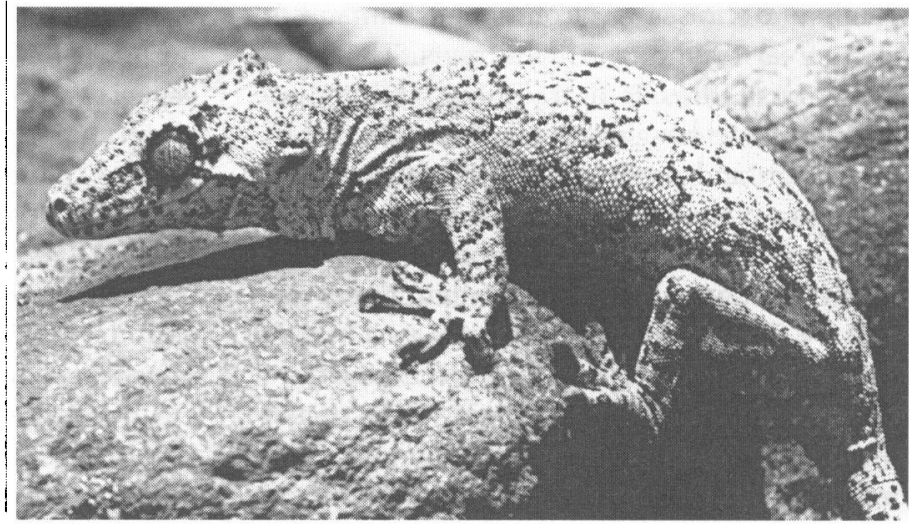


Annexed by France in 1853, New Caledonia became an Overseas Territory in 1946. Political moves to assert Melanesian sovereignty by the Kanaks resulted in the Matignon Accords of 1988, whereby the territory was divided into three provinces: North, South and Loyalties, each of which was granted limited autonomous rule. A referendum to determine whether or not New Caledonia should become independent is scheduled for 1998.

Once covering 90 per cent of New Caledonia (Association pour la Sauvegarde de la Nature Néo-Calédonienne, Nouméa, unpubl. data) forests have now been reduced to $3740 \mathrm{sq} \mathrm{km}$ (just over 20 per cent of the land area), only 10 per cent of which can be considered undisturbed (IUCN, 1986). These forests constitute the greatest component of the territory's biodiversity, including all five endemic plant families (Morat et al., 1984), and deserve particular emphasis in conservation efforts. Many of New Caledonia's lizards, birds and terrestrial invertebrates are forestdependent, such as the Rhacodactylus geckos (Bauer and Sadlier, 1993), and many of the plants and animals of these forests have very restricted ranges and are thus especially endangered by habitat loss.

The three primary causes of vegetation loss in New Caledonia have been mining, logging and bush fires. Mining is open cast and removes enormous amounts of overburden and its forest cover. Access to mines also requires cutting roads and bush tracks through forested areas. The resulting erosion is some of the worst anywhere in the world and the eroded material is often laden with heavy metals and causes environmental damage to downstream rivers and coral reefs. The starting of bush fires is a traditional Kanak activity, which has resulted in much forest conversion and probably explains the current extent of savannahs and fire-resistant niaoulis. In addition, Europeans introduced forest exploitation at a scale far greater than that practised by the Kanaks, and the once vast stands of sandalwood, rosewood and giant kauris are now mostly gone. Today, logging is restricted to a few small areas and the vast majority of timber consumed in New Caledonia is imported. However, with so much forest already depleted by past logging, even localized logging operations can have a significant impact on New Caledonia's ecology and species with highly restricted ranges.

The start of human occupation in New Caledonia over 3000 years ago released another threat to the survival of the territory's wildlife: predation, both by humans and the species they brought with them. Combined with forest habitat loss, introduced rats, cats and especially feral dogs and pigs, threaten the survival of the kagu, which is now reduced to an estimated population of 500-1000 individuals (Hannecart, 1988; Salathé and Imboden, unpubl. data) and of several other native species. A large congener of the kagu, Rhynocetus orarius, perished several centuries ago, unable to adapt from its coastal forest habitat to the rain forests where the kagu still survives (Chazeau et al., 1994). Overhunting probably contributed to the extinction of this species, as it probably also did for the crocodile Mekosuchus inexpectatus and Meiolania mackayi, a gigantic tortoise with horns on its head and armour-like plates covering its feet and tail (Balouet and Alibert, 1990). A similar fate was shared by a large monitor lizard and Sylviornis neocaledoniae, a huge galliform bird measuring over $1.3 \mathrm{~m}$ from beak to tail, which was probably contemporary with Pacific islanders on New Caledonia (Balouet and Olson, 1989; Balouet and Alibert, 1990). Another extinct species, Megapodius molestructor, was a large megapode that may have still been present when Captain Cook's arrival in 1774 started the history of Europeans in New Caledonia. Hannecart (1988) stated that hunting was still a threat to some species of birds, especially pigeons, and expressed concern about the impact of increasing tourist visits to seabird colonies. Bauer and Sadlier (1993) also cited the potential threat of rat predation to Rhacodactylus and Phoboscincus lizards and noted a decrease in both lizard diversity and abundance where an exotic ant, Wasmannia auropunctata, was present.

Since the late Quaternary, at least 11 species of non-passerine birds have become extinct (Balouet and Olson, 1989), and Bouchet et al. 
A hillside laid bare by mining (T. B. Werner).

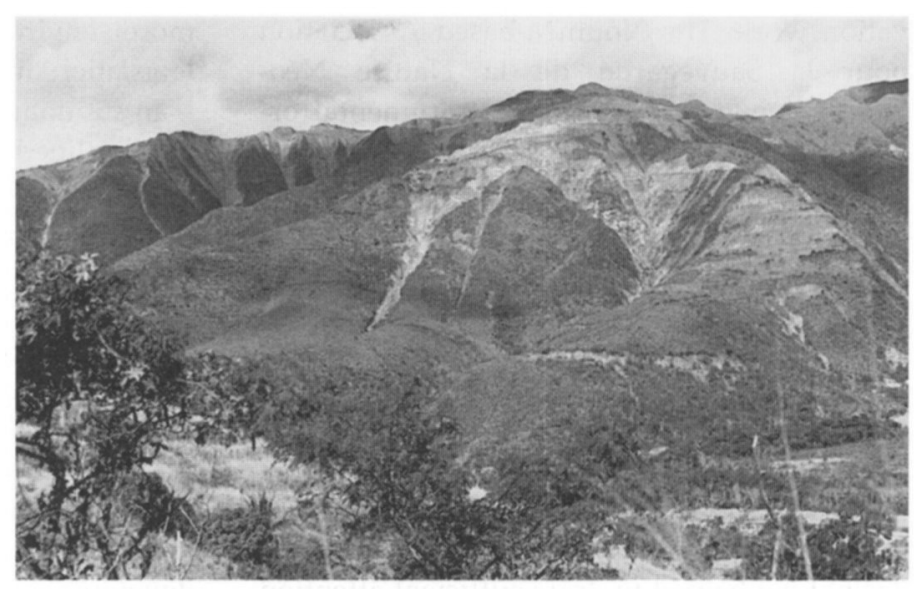

(1995) believe that perhaps as many as 10 plant species from New Caledonia are now extinct. An additional number of plants are under threat of extinction, including many with extremely restricted ranges. These include three species of palm, one of which, Pritchardiopsis jeanneneyi, was believed to be extinct until recently rediscovered. It is now found within just 1 ha of forest (Jaffré and Veillon, 1988). Although information on invertebrates is lacking, at least one snail, a lowland forest species, has not been collected since the early part of this century (CTRDP, 1987). In summary, given past extinction records and the observations that many of New Caledonia's plants and animals have small ranges, even by island standards, more extinctions appear to be inevitable unless something is done urgently. In some instances, extinction would mean not only the loss of individual species but of entire genera.

International demand for rare and unusual species, for example the Ouvéa parakeet Eunymphicus cornutus uvaeensis and the horned parakeet $E$ c. cornutus - (the only two members of an endemic genus), is another concern. Perhaps as few as 200 individuals of the former subspecies remain in the wild (Hannecart, 1988; Robinet et al., 1995). Restricted to just 2000 ha of north-east Ouvéa island, 50 young birds of this subspecies were recently exported illegally (Robinet et al., 1995).

Exploitation of marine species by traditional and recreational fisheries, and the harvesting of corals, Trochus, sponges and reef fish occur, but these are not considered serious threats at present (Kusser, 1985). Of greater concern is the pollution and sedimentation, caused by mining activities, in the lagoon surrounding Grande Terre (Dupon, 1986), although it has been reported that the situation has improved since the Societé le Nickel installed filtering dams downriver from mining operations. A recent study of air and water quality in residential neighbourhoods of Nouméa found high nickel levels (SPREP, 1993). The presence of nickel in air and water should be a major concern; the World Health Organization considers nickel too toxic to even establish a minimum human tolerance level for this element.

\section{Recommendations for the future}

Despite the global conservation significance of New Caledonia, there is little awareness about its outstanding biological diversity even within the territory itself. Given the territory's urgent development needs, both French and indigenous Kanak inhabitants are more focused on exploiting the territory's natural resources, especially in the poorer rural provinces where development needs are most urgent.

Some people in New Caledonia have recognized the conservation imperative. Action Biosphère, a local non-governmental organization, is earning high regard for its conser- 
vation work. The Nouméa-based Association pour la Sauvegarde de la Nature NéoCalédonienne, another non-governmental organization, has spent 23 years promoting conservation in New Caledonia. Among other activities, it has supported (with assistance from the French Ligue pour la Protection des Oiseaux and UK's Royal Society for the Protection of Birds) some important research work on the kagu and has devoted much of its resources to conservation education in the territory,

The kagu is an excellent flagship species for forest conservation in New Caledonia but it has not yet helped to draw sufficient attention to the vast majority of the territory's ecosystems that are neglected in conservation terms. A network of nature reserves covering 43,773 ha of the terrestrial area and approximately 50,000 ha of the marine environment (Chazeau et al., 1994) exists on paper but virtually nothing is known of the status of a large percentage of these and only the Rivière Bleu Territorial Park receives even a modicum of field management. Less than a quarter of the total area covered by terrestrial nature reserves is in Province Nord (Figure 1). No marine reserves have been designated in this province and no reserves of any kind have been gazetted in the Loyalties.

Unfortunately, many existing nature reserves may be so degraded that there may no longer be much justification for their conservation. There is an urgent need to assess better the geographic priorities for conservation, starting with a scientific rapid assessment survey of the remaining natural areas of the country, combined with thorough review of all existing biological knowledge. This survey, which should focus particularly on existing protected areas, is, in our opinion, the single highest priority for New Caledonia. In partnership with provincial and territorial governments, as well as Kanak landowners, this work should be developed into a comprehensive programme of reserve establishment and management, policy development and targeted environmental education. Equally important is the need to work within provincial development objectives to help them achieve more environmentally sound policies and legislation in resource management.

In summary, we recommend that the initiatives outlined below receive support.

1 A rapid assessment survey of existing protected areas and other natural areas to determine their current status and conservation viability.

2 Development of legislation and policies that promote biodiversity conservation and sustainable resource management, focused especially in Province Nord.

3 Establishment of models of conservation area management that integrate sustainable development, such as from ecotourism and from other environmentally sound enterprises.

4 Expansion of conservation education and public awareness.

5 Strengthening of existing and appropriate conservation legislation, policies and action.

Unfortunately, the French Government has not, in our opinion, given nearly enough attention to conservation of this unique territory's biological wealth, especially regarding the terrestrial component. On top of this, the fact that New Caledonia is the territory of a developed country, and not an independent nation, has prevented it from receiving development assistance for biodiversity conservation from bilateral and multilateral aid agencies, foundations and other donors (with the exception of the John D. and Catherine T. MacArthur Foundation). This kind of aid has made a big difference in other parts of the world deemed priority areas for biodiversity conservation. In the case of New Caledonia, lack of aid has meant a situation in which neither the international community nor the country that has jurisdiction over the territory has given it sufficient attention and, indeed, it is now by far the most overlooked of the hotspots identified by Myers some 7 years ago. This needs to change as soon as possible.

The current conservation situation in New Caledonia merits comparison with that of Madagascar a decade ago. In the early 1980s Madagascar faced a monumental challenge in conserving its rich but severely threatened biodiversity, but only a handful of donors 
Nouméa's nickel smelter, run by the Societé le Nickel (R. A. Mittermeier).

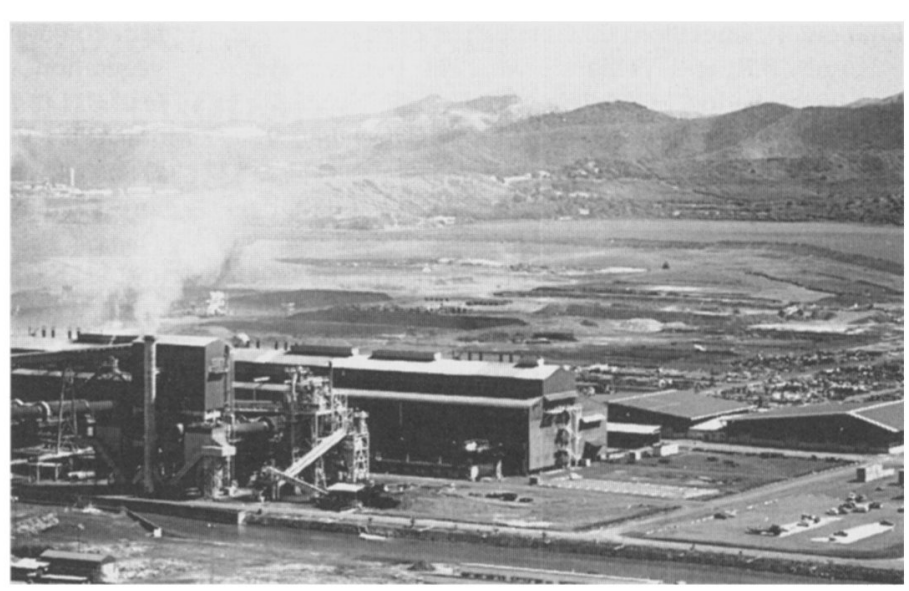

were paying it much attention. Then, in 1985 , a major national conference was held to which the national donor community (World Bank, USAID, other bilaterals, international conservation organizations such as WWF and IUCN, UN agencies, etc.) and concerned scientists and conservationists were invited. This led to a number of major programmes by organizations such as WWF, Duke University, Jersey Wildlife Preservation Trust, Missouri Botanical Garden, Conservation International and several major survey programmes of existing and potential protected areas (Nicoll and Langrand, 1989). Conservation International's COEFOR project - a project with the government's Department of Water and Forests designed to assess and design management plans for the country's classified forests - and the government's Environmental Action Plan (co-ordinated with the World Bank) continue to this day.

An effort of similar scope is now needed for New Caledonia, because the conservation imperative here is no less urgent than for Madagascar. We therefore urge the French Government, local authorities and the international conservation community to focus attention on this overlooked 'hotspot' to ensure that the world does not lose one of its great biological treasures.

\section{Acknowledgements}

The authors gratefully acknowledge the research assistance of Tina Rogers in producing this article, the reviews of Jean-Louis d'Auzon and Philippe Bouchet, and the assistance of Aaron Bauer, Jean Chazeau, Gavin Hunt and Bernard Séret. Support for this work was provided by Conservation International's Melanesia Program and the John D. and Catherine T. MacArthur Foundation's World Environment and Resources Program.

\section{References}

Anon. 1989. Atlas de Nouvelle Calédonie. Editions du Cagou, Nouméa.

Anon. 1994. The Far East and Australasia 1994, 25th edn. Europa Publications Ltd, London.

Balouet, J.C. and Olon, S.L. 1989. Fossil birds from late Quaternary deposits in New Caledonia. Smithsonian Contributions to Zoology, 469.

Balouet, J.C. and Alibert, E. 1990. Extinct Species of the World (English edn., transl. K. J. Hollyman; ed. J. Robb). Baron's Educational Series Inc., New York.

Bauer, A.M. and Sadlier, R.A. 1993. Systematics, biogeography and conservation of the lizards of $\mathrm{New}$ Caledonia. Biodiversity Letters, 1 (3/4), 107-122.

Bauer, A. and Vindum, J. 1990. A checklist and key to the herpetofauna of New Caledonia, with remarks on biogeography. Proc. Cal. Acad. Sciences, 47 (2), 17-45.

Bouchet, P., Jaffré, T. and Veillon, J.-M. 1995. Plant extinction in New Caledonia: protection of sclerophyll forests urgently needed. Biodiversity and Conservation, 4, 415-428.

Chazeau, J. 1993. Research on New Caledonia terrestrial fauna: achievements and prospects. Biodiversity Letters, 1 (3/4), 123-129. 
Chazeau, J., Chevillon, C., Garrigue, C., Jaffré, T., de Forges, B.R. and Veillon, J.-M. 1994. Biodiversité et conservation en Nouvelle-Calédonie. Rapports de Syntheses (Sciences de la Vie: Biodiversité), 1. ORSTOM, Nouméa.

CTRDP, 1987. Ecologie en Nouvelle-Calédonie. CTRDP, Nouméa.

Dupon, J.F. 1986. The effects of mining on the environment of high islands: case study of nickel mining in New Caledonia. Environmental Case Studies, South Pacific Study. 1. SPREP, Nouméa.

Farjon, A., Page, C.N. and Schellevis, N. 1993. A preliminary world list of threatened conifer taxa. Biodiversity and Conservation, 2, 304-326.

Flannery, T. 1995. Mammals of the South-West Pacific and Moluccan Islands. Cornell University Press, Ithaca, New York.

Guile, A., Laboute, P. and Menou, J.-L. 1986. Guide des Etoiles de Mer, Oursins et autres Echinodermes de Lagon de Nouvelle Calédonie. ORSTOM, Paris.

Hannecart, F. 1988. Les oiseaux menacés de la Nouvelle Calédonie et des îles proches. In Livre Rouge des Oiseaux Menaces des Regions Françaises d'Outre-Mer (eds J.-C. Thibault and I. Guyot), pp. 143-165. ICBP Monograph No. 5. ICBP, Cambridge.

Hannecart, F. and Letocart, Y. 1980. Oiseaux de Nouvelle Calédonie et des Loyautes Vol. 1. Clark and Matheson Ltd, Auckland.

Hannecart, F. and Letocart, Y. 1983. Oiseaux de Nouvelle Calédonie et des Loyautes Vol. 2. Dai Nippon, Hong Kong.

Holloway, J.D. and Peters, J.V. 1976. The butterflies of New Caledonia and the Loyalty Islands. J. nat. Hist. 10, 273-318.

IUCN. 1986. Review of the Protected Areas System in Oceania. IUCN, Gland, Switzerland.

Jaffré, T. 1993. The relationship between ecological diversity and floristic diversity in New Caledonia. Bodiversity Letters, 1 (3/4), 82-87.

Jaffré, T. and Veillon, J.-M. 1988. Morphologie, distribution and écologie des palmiers de Nouvelle Calédonie. Rapports Scientifiques et Techniques (Sciences de la Vie: Botanique), 2. ORSTOM, Nouméa.

Jaffré, T., Morat, Ph., Veillon, J.-M. and MacKee, H.S. 1987. Changements dans la végétation de la Nouvelle-Calédonie au cours du Tertiaire: la végétation et la flore des roche ultrabasiques. $B$ ull. Mus. natn. Hist. nat., Paris, 4e ser., 9, 1987, section B. Adansonia, 4, 365-391.

Kusser, J. 1985. Marine Reserves in New Caledonia. A case study prepared for the Third South Pacific National Parks and Reserves Conference and Ministerial Meeting, Apia, Western Samoa, 24 June-3 July, 1985.

Morat, $\mathrm{Ph}$. 1993. Our knowledge of the flora of New
Caledonia: endemism and diversity in relation to vegetation types and substrates. Biodiversity Letters, 1 (3/4), 72-81.

Morat, Ph., Veillon, J.-M. and MacKee, H.S. 1984. Floristic relationships of New Caledonian rain forest phanerograms. In Biogeography of the Tropical Pacific (eds F. J. Radovsky, P. H. Raven and S. H. Sohmer), pp. 71-128. ASC, Kansas.

Myers, N. 1988. Threatened biotas: 'hot spots' in tropical forests. The Environmentalist, 8 (3), 187208.

Myers, N. 1990. The biodiversity challenge: expanded hot-spots analysis. The Environmentalist, 10 (4), 243-256.

Nicoll, M.E. and Langrand, O. 1989. Madagascar: Revue de la Conservation et des Aires Protégées. WWF, Gland, Switzerland.

Platnick, N.I. 1993. The araneomorph spider fauna of New Caledonia. Biodiversity Letters, 1 (3/4), 102-106.

Rivaton, J., Fourmanoir, P., Bourret, P. and Kulbicki, M. 1989. Catalogue des poissons de NouvelleCalédonie. Catalogues Sciences e la Mer (Biologie Marine). ORSTOM, Nouméa.

Robinet, O. Beugnet, F., Dulieu, D. and Chardonnet, Ph. 1995. The Ouvéa parakeet - state of knowledge and conservation status. Oryx, 29, 143-150.

Salathé, T. and Imboden, C. Saving the kagu: a recovery plan for New Caledonia's national bird. Unpubl. ms. ICBP, Cambridge.

Salvat, B., Rives, C. and Revercé, P. 1953 (1988 edn). Coquillages de Nouvelle Calédonie. Times Editions, Singapore.

Schmid, M. 1981. Fleurs et Plantes de NouvelleCalédonie. Les editions du pacifique.

Séret, B. 1992. Poissons d'eau douce du 'Caillou'. ORSTOM Actualités, 37, 2-7.

SPREP. 1993. Health risk from nickel smelter in Nouméa. Environment Newsletter, 35, 8.

UNEP/IUCN. 1988. Coral Reefs of the World. Vol. 3: Central and Western Pacific. UNEP Regional Seas Directories and Bibliographies. IUCN, Gland Switzerland and Cambridge, UK/UNEP.

Russell A. Mittermeier, President, Conservation International, 1015 18th St NW, Washington, DC 20036, USA and Department of Anatomical Sciences, Health Sciences Center, State University of New York, NY 11794-8081, USA.

Timothy Werner, Director, Melanesia Program, Conservation International, 1015 18th St NW, Washington, DC 20036, USA.

Annette Lees, Melanesia Program Manager, Conservation International/Maruia Society, 143 Bethells Road, Henderson, Auckland 8, New Zealand. 